\title{
Identification of materials used in a wooden coffin lid covered with composite layers dating back to the Ptolemaic period in Egypt
}

\author{
Nour Mohamed Badr ${ }^{1, *}$ (D) \\ Mona Fouad Ali² \\ Nesrin M. N. El Hadidi² \\ Gamal Abdel Naeem ${ }^{3}$ \\ ${ }^{1}$ Conservation Centre, Grand Egyptian Museum, Ministry of Antiquities, El Mathf Elmasry ElKebir (Grand \\ Egyptian Museum) St., El-Remaya Sq., 12572 Giza, Egypt \\ ${ }^{2}$ Conservation Department, Faculty of Archaeology, Cairo University, 12613 Giza, Egypt \\ ${ }^{3}$ Department Advanced Technologies - Scientific Research, 21934 Burj Al Arab, Alexandria, Egypt \\ *dr_noor_90000@yahoo.com
}

\begin{abstract}
A wooden coffin lid, of unknown provenance, with ground and colored layers and an ancient textile, was found at the Egyptian Museum basement in Cairo (JE 36806). The information obtained leads to the conclusion that the coffin lid dates back to the Ptolemaic period in Egypt (332-30 BC), whereas the textile does not belong to the coffin lid. Portable x-ray radiography, photography, optical microscopy, reflected light USB microscopy, Fourier transform infrared spectroscopy with attenuated total reflection (FTIR-ATR), energy-dispersive X-ray spectroscopy (EDX), X-ray diffraction (XRD) and Raman spectroscopy were used to assess the deterioration and the structure of the coffin lid and to understand how it was made in the necropolis workshop.
\end{abstract}

Identificação dos materiais usados na tampa de um sarcófago de madeira com estrutura compósita do período Ptolemaico do Egipto

\section{Resumo}

A tampa de um sarcófago de madeira, de proveniência desconhecida, com camadas de preparação e cromática e têxteis antigos, foi encontrada na cave do Museu Egípcio, no Cairo (JE 36806). A informação obtida permitiu a concluir que a tampa remonta ao período Ptolemaico do Egipto (332-30 a. C.), enquanto o têxtil não pertence à tampa. Para avaliar a deterioração e a estrutura da tampa do sarcófago e perceber como foi feita na oficina da necrópole, foi usada radiografia de raios $X$, fotografia, microscopia óptica, microscopia USB de luz reflectida, espectroscopia de infravermelho com transformada de Fourier com reflexão total atenuada (FTIR-ATR), espectroscopia de raios $X$ dispersiva de energia (EDX), difracção de raios $X(X R D)$ e espectroscopia de Raman.

\section{Keywords}

Wooden coffin

Abusir El-Meleq

Ptolemaic period

Egyptian Museum in Cairo

Pigments

Binding media

\section{Palavras-chave}

Sarcófago de madeira

Abusir El-Meleq

Período Ptolemaico

Museu Egípcio do Cairo

Pigmentos

Aglutinante 


\section{Introduction}

Recent work in the basement of the Egyptian Museum in Cairo led to the rediscovery of a coffin lid of unknown provenance covered with two linen layers (Figure 1). The excavation diary of Otto Rubensohn mentions that the coffin was found in a family tomb at Abusir El-Meleq in 1903-1904, in the northern part of Middle Egypt [1-2]. Five stone sarcophagi were found in a burial grave, each containing a wooden coffin. The coffin lid, with register number JE 36806 at the Egyptian Museum in Cairo, was the third coffin in that find and belonged to Sema-taui, son of Ahmose [3]. It was decorated with many colors, but due to poor preservation conditions during centuries of burial, severe contraction of the wood led to the detachment of the paint layers (Figure 2a) [1].

Two questions related to this lid emerged during work, namely: 1) why was the coffin box of Sema-taui exhibited in the Egyptian Museum, with its mummy and cartonnage, under different register numbers?; 2) why were textile layers found on the lid? The answer for the first question was not found, but an explanation for the second question would be that probably the textile was incorrectly placed on the coffin lid after its transfer from the excavation site to the museum basement. So far it cannot be definitely excluded that the textile layers, which formed an Osiris shroud (Figure 2b), belonged to the mummy of this coffin. Germer mentioned that one of the mummies found in this burial had an outer linen shroud with designs imitating a net with blue and white faience beads, yet no other reference mentioned the Osiris shroud [3].

In the literature there are examples of coffins that had been covered with textiles in ancient Egypt; nevertheless it is difficult to confirm that the textile shroud on the coffin lid in this study belongs to the coffin. The most famous example is the inner coffin of King Tutankhamun, dating back to the 18th Dynasty, New Kingdom. Other examples include the coffin of Sennefer from Deir el Medineh, also dating back to the New Kingdom [4-6], and the two coffins found by Howard Carter and Lord Carnarvon in 1912-1915 in Upper Egypt, namely the shrouded coffin of Bakamun (called Baki) in the tomb of Neferkhawt and the coffin of a woman called Maarti [6, p. 168].

Careful removal of the textile layers revealed an anthropoid-shaped coffin lid covered with a painted gesso layer, depicting a blue headgear, a pink face with beard, a broad collar formed of strips of floral and geometric shapes, and an image of the sun-god as a winged scarab beetle. The central full-face figure was that of the skygoddess Nut, on whose body the text of chapter 89 of the Book of the Dead was written.

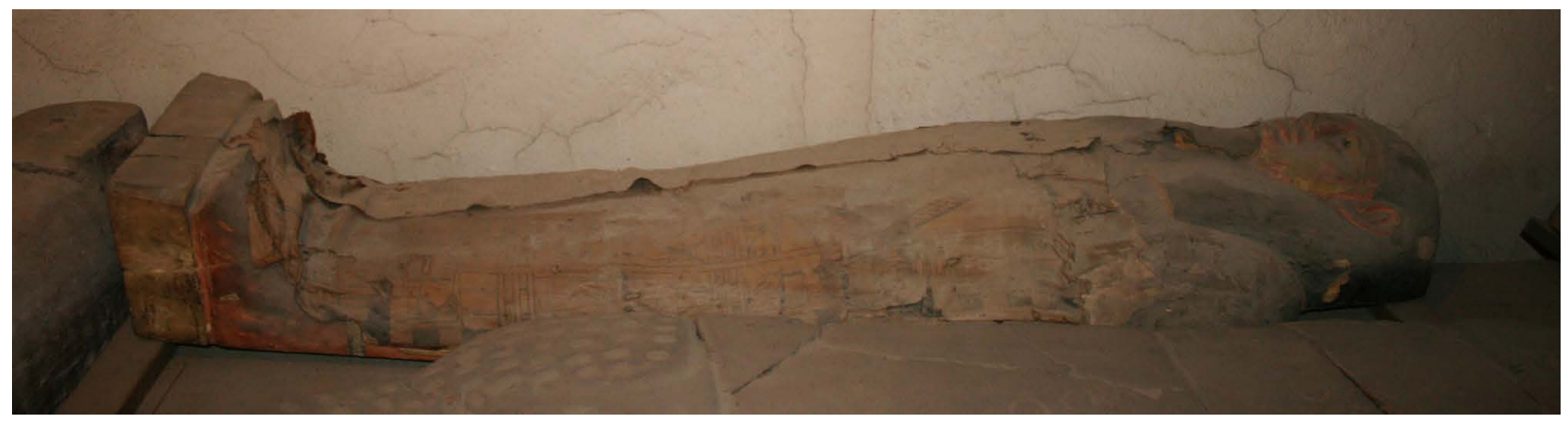

Figure1. Coffin lid (JE 36806) covered with textile layers at the basement of the Egyptian Museum in Cairo.

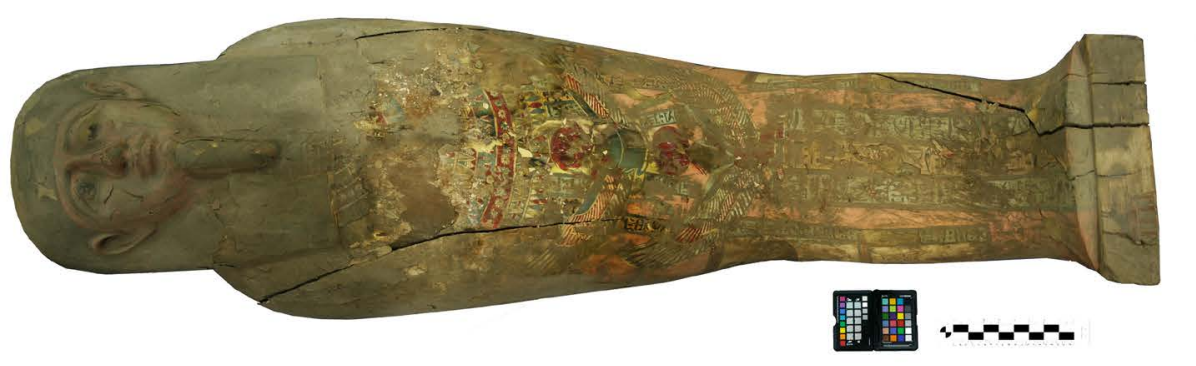

a

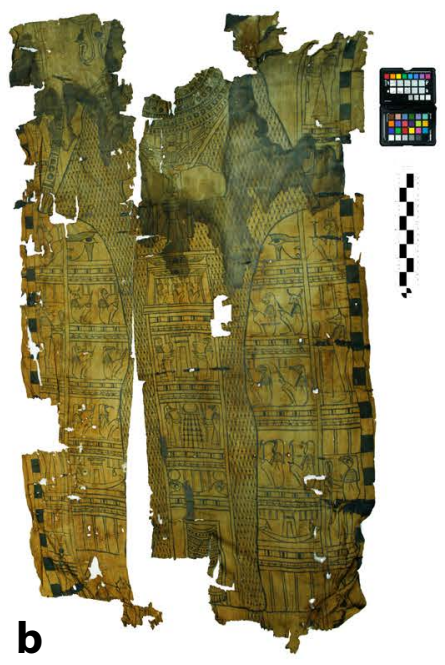

Figure 2. a) Wooden coffin lid after the removal of the textile layers; $b$ ) the textile layers after their removal from the coffin lid. 

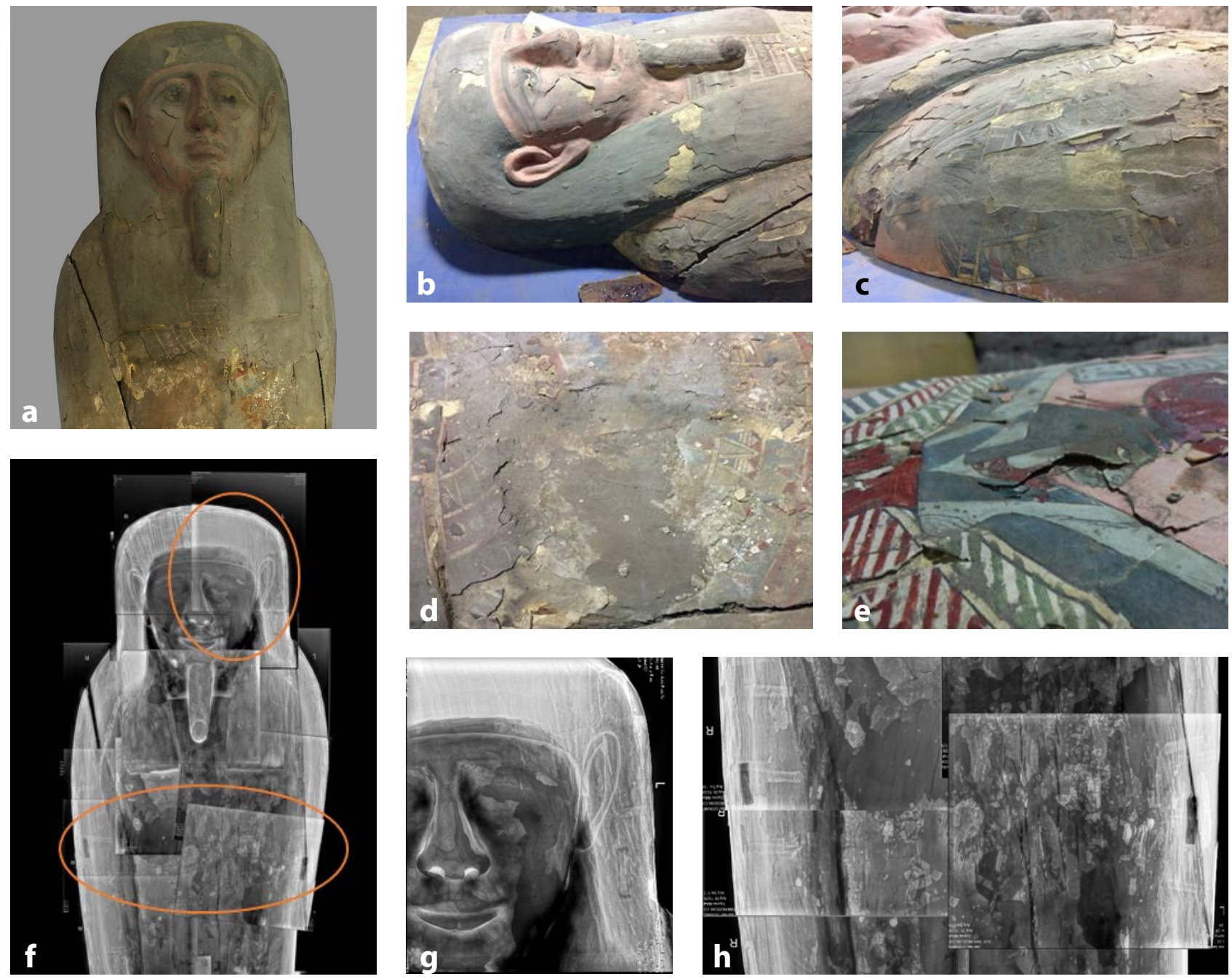

Figure 3. Documentation of the deterioration aspects due to wood shrinkage: $a$ ) separation in the wooden parts; $b$-e) flaking, separation, cupping and overlap of the painted gesso layer; $f$-h) X-ray radiograph pictures $(70 \mathrm{kV}, 1 \mathrm{~s}, 35 \mathrm{~mA})$ showing details of the deterioration aspects not visible to the naked eye, e.g. longitudinal cracks and gaps under the painted gesso layer.

\section{Research aim}

The aim of this study was to identify and study the structural composition (grounds, pigments and media) of the Ptolemaic wooden coffin lid by using non-destructive investigation techniques and analytical methods. The obtained data was used to document the coffin lid and present initial observations of the ancient workshop during the Ptolemaic period (332-330 BC) in ancient Egypt and to assess the object condition in order to set a future treatment and conservation plan.

The assessment of deterioration aspects by visual observation was performed by photography (Figures 3a$3 \mathrm{e}$ ) and X-ray radiography (Figures $3 \mathrm{f}-3 \mathrm{~h}$ ), in order to document the main deterioration factor - wood shrinkage - and its effects.

\section{Material and methods}

\section{Samples}

This study depended mainly on non-destructive analysis and investigation methods. Microscopic investigation was applied to the fragmented flakes (surface and cross section). In specific cases, a very small textile fiber and thin wood section (three directions) from detached loose samples were placed on glass slides and examined using a stereo microscope with an attached digital camera.

Other small fragments were used for analytical methods, which included FTIR-ATR, EDX, XRD and Raman, without damaging the samples in order to return them back to their original position on the coffin lid.

\section{Portable X-ray radiography}

Portable X-ray radiography, using a Cuattro Slate $25 \times 30 \mathrm{~cm}$ wireless Cesium-I Detector system with a tablet monitor, was used for the assessment of the deterioration aspects and all results were compared with those found in previously published research.

\section{Reflected USB digital microscopy}

Surface morphology and stratigraphic structure of the painted layers fragments were studied using Veho 
USB digital microscope with visible light and Dino-Lite AM4113T USB digital microscope with UV-IR light and 1.3 MP digital camera (its variable magnification ranging from 20 to $200 \times$, depending on the working distance and the sample).

\section{Optical microscopy}

Upright microscopy using a Zeiss Axio Imager M1 with an Axio Cam was used to investigate and identify the textile fiber and the wooden sections (200-400×).

\section{Fourier transform infrared spectroscopy coupled with attenuated total reflection (FTIR-ATR)}

Sample fragments were analyzed with a FTIR spectrometer Vertex 70 (Bruker) with ATR crystal accessory (Platinum diamond ATR) and standard MIR source, at $2 \mathrm{~mm} / \mathrm{sec}$ in the spectral region ranging from 4000 to $500 \mathrm{~cm}^{-1}$ with $4 \mathrm{~cm}^{-1}$ resolution, to identify the organic binding media and some inorganic functional groups in the painted layer.

\section{Energy-dispersive X-ray spectroscopy (EDX)}

Sample fragments were analyzed by a energy-dispersive X-ray spectrometer model FEI Quanta 200, with a field-emission source, offering a wide range of operating conditions, in which specimens can be examined with high chamber pressure environment. The X-ray analysis was carried out at $20 \mathrm{kV}$ accelerating voltage. This technique was used to determine the elements in each layer of the painted gesso. The samples were examined in cross section in order to differentiate between the two types of ground layers and the colored layer of the painted surface.

\section{X-ray diffraction (XRD)}

Sample fragments were placed on glass slides and analyzed with X-ray diffractometer PANalytical pro model PW3040 with a Cu-target tube and Ni filter at 40 $\mathrm{kV}$ and 30 MA. X'Pert High score software was used for identifying the components of the painted layers.

\section{Raman spectroscopy}

Sample fragments were analyzed to confirm some of the XRD and FTIR results of the inorganic and organic compounds using a Senterra Raman spectrometer (Bruker) with a $20 \times$ objective lens and $785 \mathrm{~nm}$ lasers with 5-20 second integration times and 1-10 $\mathrm{mW}$ power. Spectra were recorded from 0 to $4000 \mathrm{~cm}^{-1}$. Raman spectra were subjected to baseline correction and smoothed.

\section{Results and discussion}

\section{Wooden support}

Ancient Egyptian craftsmen dealt with the constraints and limitations of available materials [7]. The coffin lid of Sema-taui appears to be yet another example of such workmanship. It was made of a large hollowed out tree trunk and four planks attached to the main part with wooden dowels. The microphotographs of wood
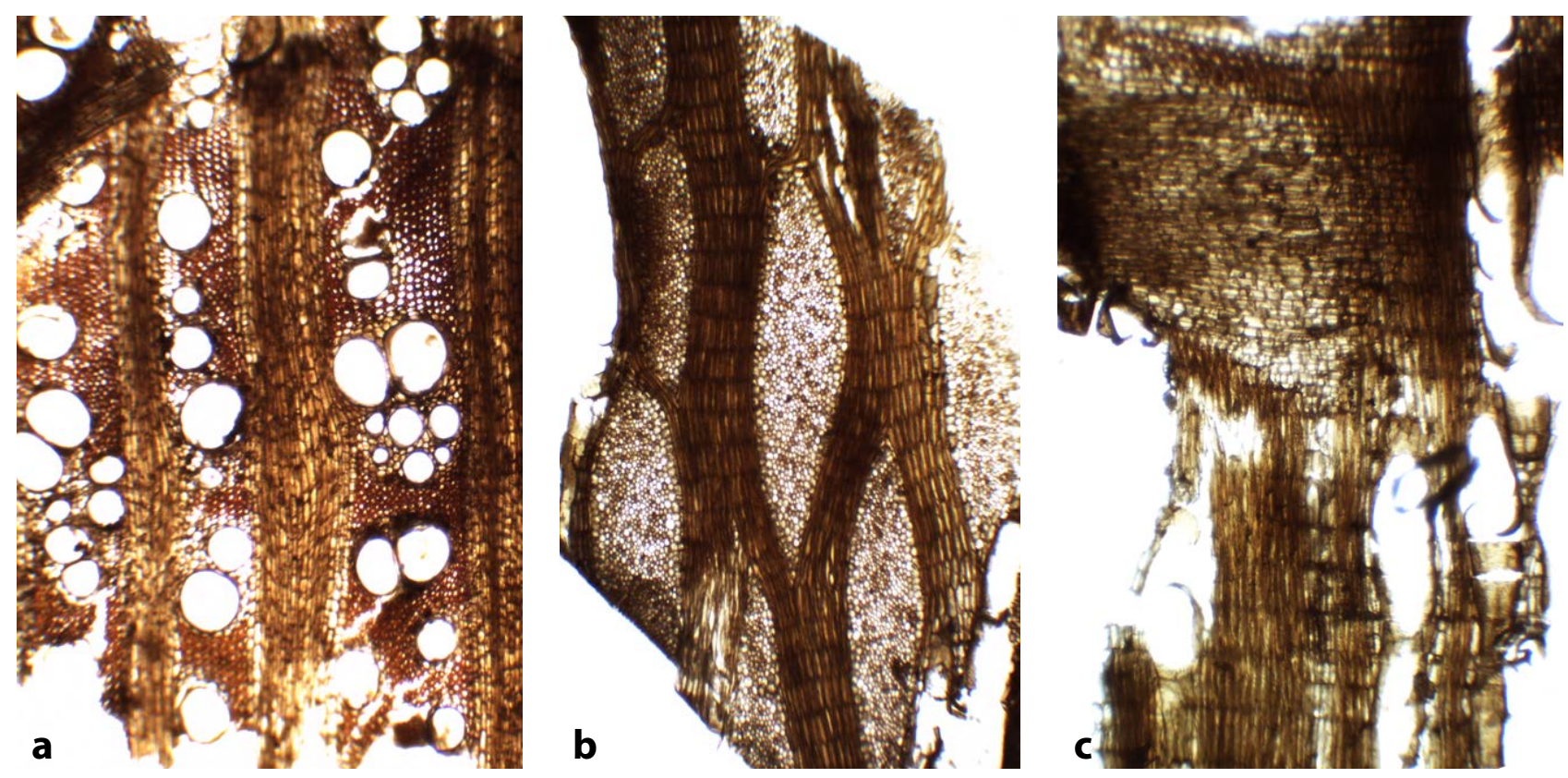

Figure 4. Tamarix $s p .:$ a) transverse section showing semi-ring porous vessels, solitary and in small clusters (200x); b) longitudinal section showing larger rays commonly more than 10 seriate; axial parenchyma and vessel elements storied $200 \times ; c$ ) tangential section showing rays commonly 2 to 7 seriate, axial parenchyma storied with simple perforation plates $200 \times$. 
thin sections (manually prepared) were taken from the main plank and examined under optical microscopy for identification. The characteristic anatomical features of Tama sp. in transverse section included semi-ring porous vessels, solitary and in small clusters (Figure 4a). In longitudinal section, larger rays, commonly more than 10 seriate, axial parenchyma and vessel elements storied were recorded (Figure 4b). Tangential section showed rays, commonly 2 to 7 seriate, and axial parenchyma storied with simple perforation plates (Figure 4c). Two common species of Tamarix are native in Egypt (Tamarix aphylla with rays exceeding sometimes 20 cells width, and Tamarix tetragyna with narrower rays [8-10]) but it was not possible to confirm the wood species used in the coffin lid.

Tamarix wood is often identified in ancient Egyptian artifacts, including coffins [11-14], yet few studies have been undertaken to study materials used in wooden coffins dating back to the Ptolemaic period in Egypt [9].

Tamarix wood, like most types of wood, shrinks in different ratios, in tangential, radial and longitudinal directions of the sawn boards or planks [15]. The major part of the lid was formed by a hollowed out tree trunk, which led to numerous longitudinal cracks, some of which penetrated through the depth of the wood and caused warping, which partly explains the occurrence of detached areas in the painted layers (Figures $3 \mathrm{f}-3 \mathrm{~h}$ ).

\section{Ground layers}

The term gesso describes the preparation layer applied to produce a smooth painting surface [1617]. Investigation of the painted gesso layer (grounds, pigments and binding medium) was primarily done by USB digital microscope under visible light. The ground layer in cross section showed that a paint layer had been applied on two kinds of preparation layers: the lower coarse-grained ground layer, and the upper fine-grained layer. A yellow color may have been added to the bottom ground layer to distinguish this layer from the upper white ground layer (which was applied directly under the paint layer) or the yellowish hue could be due to the binding medium. This was clearly seen while studying the cross section in the red, pink and green color layers, but in the blue cross section the yellow ground layer is directly under the blue pigment.

In the FTIR spectrum (Figure 5a) the following bands were found: 1631 and $1076 \mathrm{~cm}^{-1}$ due to $\mathrm{OH}$ stretching, $1394 \mathrm{~cm}^{-1}$ due to asymmetric $\mathrm{CO}_{3}$ stretching and 871 and $711 \mathrm{~cm}^{-1}$ to $\mathrm{O}-\mathrm{C}-\mathrm{O}$ bending. The last bands are attributed to calcite $\left(\mathrm{CaCO}_{3}\right)$ [18].

The EDX analysis showed that the main elements in the lower coarse-grained, yellow ground layer, are calcium and silicon, which are attributed to the presence of calcite and quartz. However, the upper layer is a fine grained layer with calcium as the main element and only traces of silicon, which are attributed to calcite with a silicon impurity, Fe or As elements were not detected
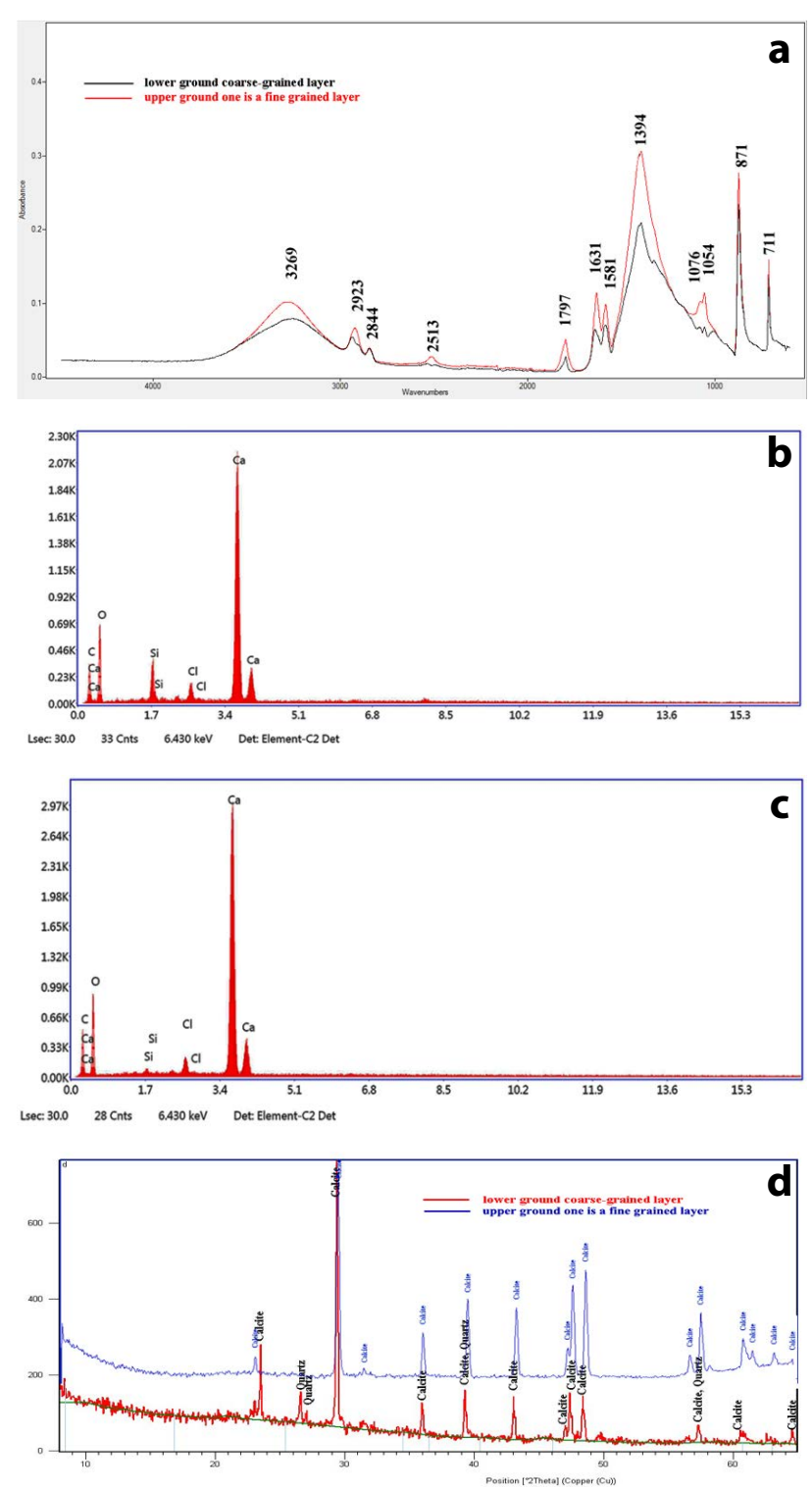

Figure 5. Ground layer: $a$ ) FTIR-ATR spectra of both ground layers; $b$ ) EDX spectrum of lower coarse-grained ground layer; c) EDX spectrum of upper fine-grained ground layer; $d$ ) XRD spectra of both ground layers.

in the lower ground layer with the yellowish hue, which indicates that the yellow color is not due to an inorganic pigment but could be, therefore, from the binding medium (Figures 5b-5c). The XRD analysis proved that the main compounds in the lower coarse-grained ground layer are calcite and silica, but in the upper fine-grained layer the main compound is calcite (Figure $5 \mathrm{~d}$ ).

These results agree with previously published research on ancient Egyptian wooden artifacts, where the ground layer can either be composed of a single structured layer or two gesso preparation layers: a lower ground coarsegrained layer to cover the wood defects, as well as to bond with wooden panels and give a flat surface, and an upper fine-grained layer. In ancient Egyptian polychromic wooden artifacts the main compound of the preparation layer is calcite [14, 19-20]. 


\section{Painted layer}

\section{Blue pigment}

Investigation of the blue pigment by USB microscopy showed that the pictorial layer, which is fairly thick, has different chromatic degrees, ranging from pale green to dark blue, and particles with different grain size (Figure 6). The FTIR-ATR spectrum (Figure 7a) exhibits bands at 1323,1155 and $1056 \mathrm{~cm}^{-1}$. These bands are attributed to a symmetrical $\mathrm{Si}-\mathrm{O}-\mathrm{Si}$ stretching vibration of amorphous silica, while the bands at 752 and $665 \mathrm{~cm}^{-1}$ are assigned to the symmetrical $\mathrm{Si}-\mathrm{O}-\mathrm{Si}$ stretching vibrations of crystalline silica [21-22].

The EDX analysis (Figures 7b-7c) showed that the main elements are copper, calcium, silicon and traces of iron. The XRD data show that light blue pigment particles are cuprorivaite $\left(\mathrm{CaCuSi}_{4} \mathrm{O}_{10}\right)$, quartz $\left(\mathrm{SiO}_{2}\right)$ and calcite $\mathrm{CaCO}_{3}$ (Figure 7d), and dark blue particles are cuprorivaite, quartz, calcite and cuprite $(\mathrm{CuO})$ (Figure 7e). No Raman bands were recorded for the blue pigment samples (785 nm laser) because Egyptian Blue, upon excitation in the visible and NIR, exhibits strong fluorescence emission with a maximum at about $890 \mathrm{~nm}$ [23].

The USB microscope images, FTIR-ATR, EDX and XRD analysis confirmed that the blue pigment was made of Egyptian blue, with two color degrees. The Fe and $\mathrm{S}$ elements detected by EDX analysis indicate that desert sand, which includes pyrite $\left(\mathrm{FeS}_{2}\right)$, was used as a raw ingredient. Pyrite is difficult to detect by XRD analysis because of its minute percentage. Egyptian blue was used from about the Fourth Dynasty (c. 2639 to 2504 BC) to the Roman period (30 BC to $395 \mathrm{AD}$ ) [24]. It was the most famous synthetic pigment in history; it was fabricated by mixing and heating (at around $850-950{ }^{\circ} \mathrm{C}$ ) quartz, copper, calcite and flux (alkali flux or plant ashes) together [25].

Microscopic investigations showed a light blue pigment layer with coarse morphology of the surface, different chromatic degrees ranging from blue to pale green crystals, and glaze matrix between the blue crystals indicating a heating temperature higher than $900{ }^{\circ} \mathrm{C}$. Quartz is a primary mineral in the mixture and the presence of glass indicates high flux content (alkali flux or wood ashes). If the heating temperature ranges between
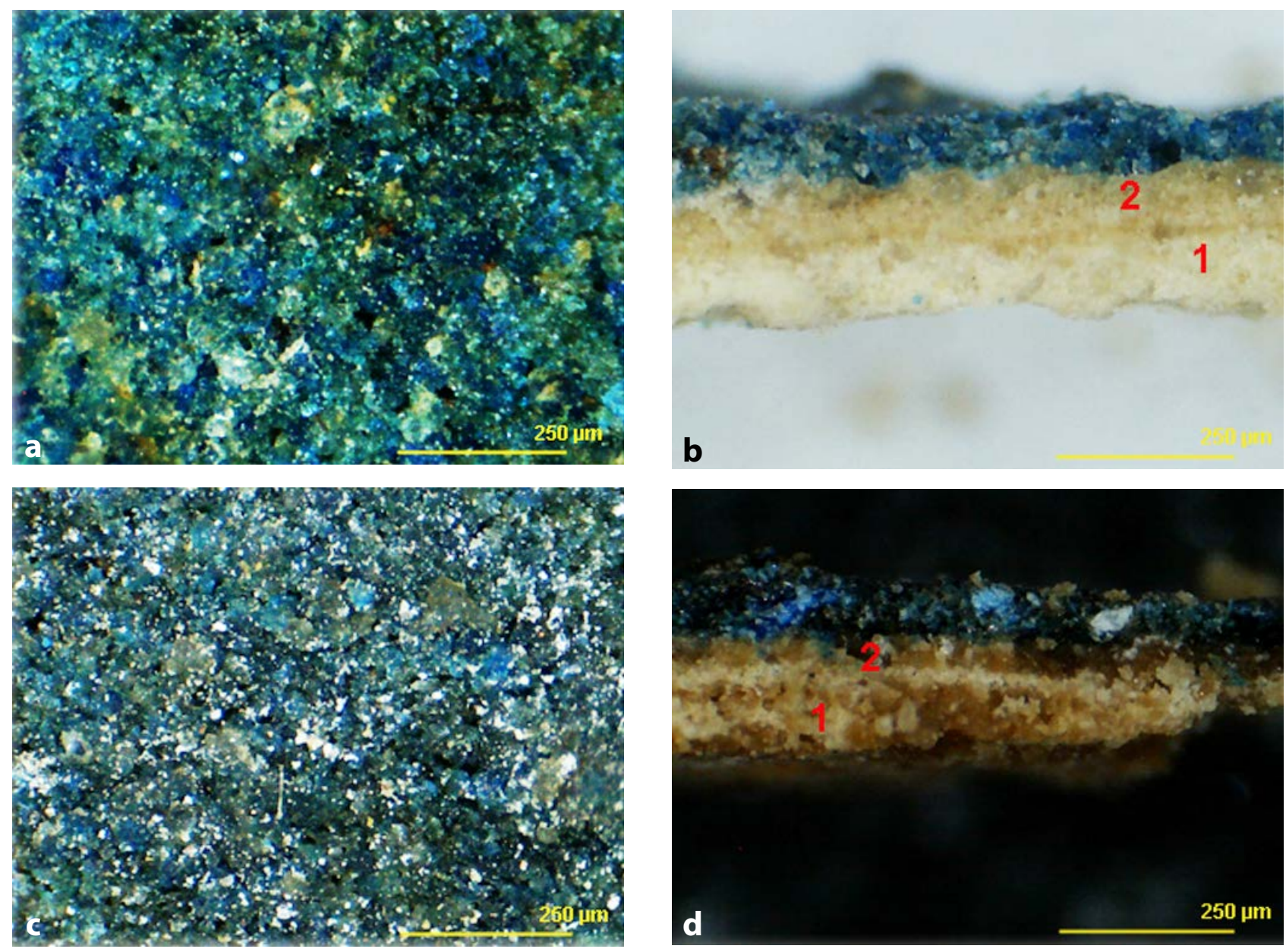

Figure 6. Blue pigment: $a-b$ ) light blue pigment layer with coarse morphology, different chromatic degrees ranging from blue to pale green crystals and glaze matrix between the blue crystals; $c$ - $d$ ) dark blue pigment layer with coarse morphology, different crystal blue color, white and transparent yellow. 

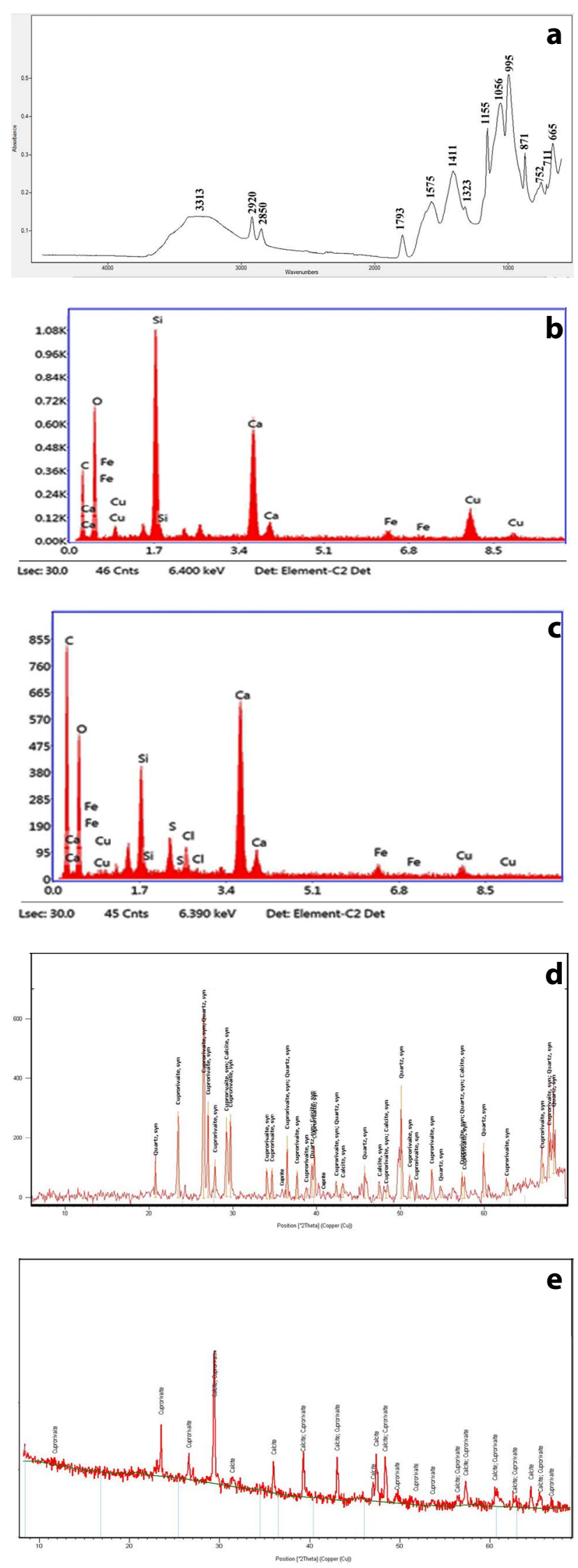

Figure 7. Blue pigment: a) FTIR-ATR spectrum of blue pigment; b) EDX spectrum of light blue pigment; $c$ ) EDX spectrum of dark blue pigment; $d$ ) XRD spectrum of light blue pigment; $e$ ) XRD spectrum of dark blue pigment.
800-850 ${ }^{\circ} \mathrm{C}$ a dark blue pigment layer with coarse surface morphology appears with different crystal colors composed of blue, white and transparent yellow [26-29].

\section{Red pigment}

Investigation of the red pigment by reflected light USB microscopy with visible light showed that the red layer was a dark red, glossy and saturated layer (Figures 8a-b). The UV and IR images show that this glossy and saturated layer is not due to conservation materials that cover the paint layer, but is a mixture of pigment particles, as clearly seen in cross section by IR light (Figures 7c$7 \mathrm{e}$ ). This shiny layer may have occurred during mixing of the red pigment with a large amount of binding medium. The FTIR-ATR spectrum exhibits two bands at 711 and $661 \mathrm{~cm}^{-1}$ assigned to $\mathrm{Fe}-\mathrm{O}-\mathrm{Fe}$ and $\mathrm{Fe}-\mathrm{O}$ stretching vibrations of hematite $\left(\mathrm{Fe}_{2} \mathrm{O}_{3}\right)$ (Figure 9a). The EDX analysis showed that the main elements are $\mathrm{Fe}, \mathrm{Ca}$, and Si (Figure 9b). The XRD data proved that the red pigment is red ochre $\mathrm{Fe}_{2} \mathrm{O}_{3}$ (Figure 9c). This result is confirmed by typical peaks of hematite at 620,505 and $219 \mathrm{~cm}^{-1}$ in the Raman spectrum (Figure 9d) and the band at $442 \mathrm{~cm}^{-1}$ indicates well-crystallized hematite [22, 30-34].

Red earth or red ochre (hematite) of varying degrees of crystallinity was the most commonly used and reported red pigments during all ancient Egyptian periods [30, 35]. Samples containing a small proportion of other minerals, including quartz, are best described as ochre, rather than as pure hematite. Red ochre $\left(\mathrm{Fe}_{2} \mathrm{O}_{3}\right)$ contains impurities, normally clay minerals, calcite and quartz [34].

\section{Pink pigment}

Investigation of the pink pigment by USB microscopy with visible light showed a mixture of red and white grains (Figures 10a-10b). The investigation of the pink pigment in cross section by UV light did not detect any fluorescence that could be attributed to an organic colorant such as madder lake (Figures 10c-10e). The FTIR-ATR spectrum exhibits bands at 3521, 3396 and $3240 \mathrm{~cm}^{-1}$ (asymmetric) attributed to O-H stretching, bands at 1107 and $1027 \mathrm{~cm}^{-1}$ (asymmetric) attributed to $\mathrm{SO}_{4}$ stretching and bands at $667 \mathrm{~cm}^{-1}$ attributed to gypsum $\left(\mathrm{CaSO}_{4} \cdot 2 \mathrm{H}_{2} \mathrm{O}\right.$ ). The band at $1413 \mathrm{~cm}^{-1}$ (asymmetric) is identified as a $\mathrm{CO}_{3}$ stretching and a $\mathrm{O}-\mathrm{C}-\mathrm{O}$ bending band, and the band at $871 \mathrm{~cm}^{-1}$ is attributed to calcite. Two bands at 711 and $667 \mathrm{~cm}^{-1}$ are assigned to $\mathrm{Fe}-\mathrm{O}-\mathrm{Fe}$ and $\mathrm{Fe}-\mathrm{O}$ stretching vibrations of hematite $\left(\mathrm{Fe}_{2} \mathrm{O}_{3}\right)[22,35]$.

The EDX analysis showed that the main elements are $\mathrm{Ca}, \mathrm{Si}, \mathrm{S}$ and $\mathrm{Fe}$. Hematite, calcite and gypsum were evident in the XRD spectrum. These results were confirmed by typical Raman bands at 620, 492, 412, $279,232 \mathrm{~cm}^{-1}$ attributed to hematite, 1085 and $175 \mathrm{~cm}^{-1}$ attributed to calcite and 1139, 1007, 620, $412 \mathrm{~cm}^{-1}$ attributed to gypsum [22, 30-34].

These results are in accordance with the fact that in ancient Egypt pink was usually obtained from a mixture 

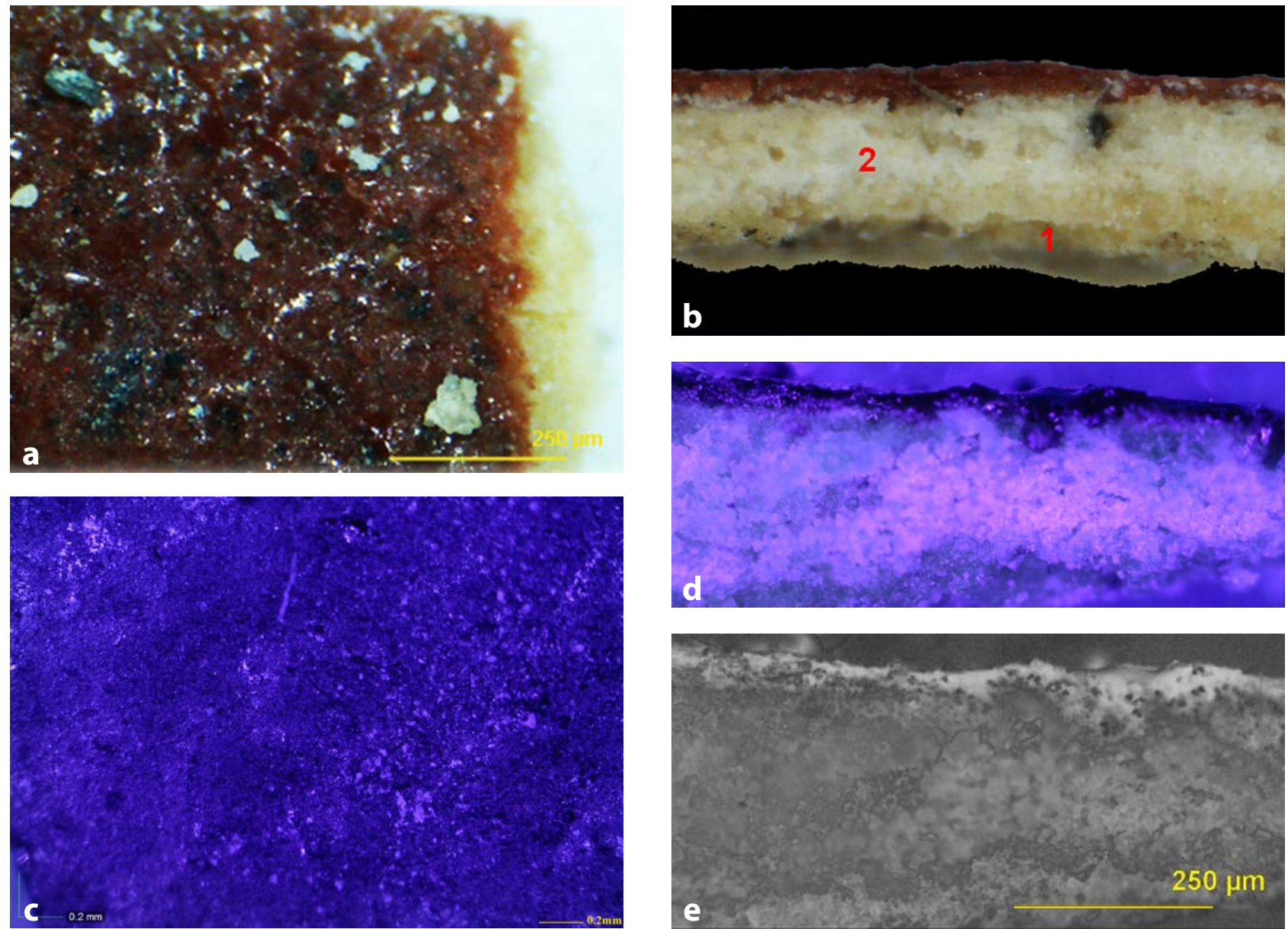

Figure 8. Red pigment: $a-b$ ) reflected USB microscopy with visible light of dark red pigment layer with homogeneous glossy and saturated layer; $c-e$ ) reflected USB microscopy with UV and IR light showed that this glossy and saturated layer is not due to conservation materials that cover the paint layer, but is a mixture of pigment particles, as clearly seen in cross section by IR light.
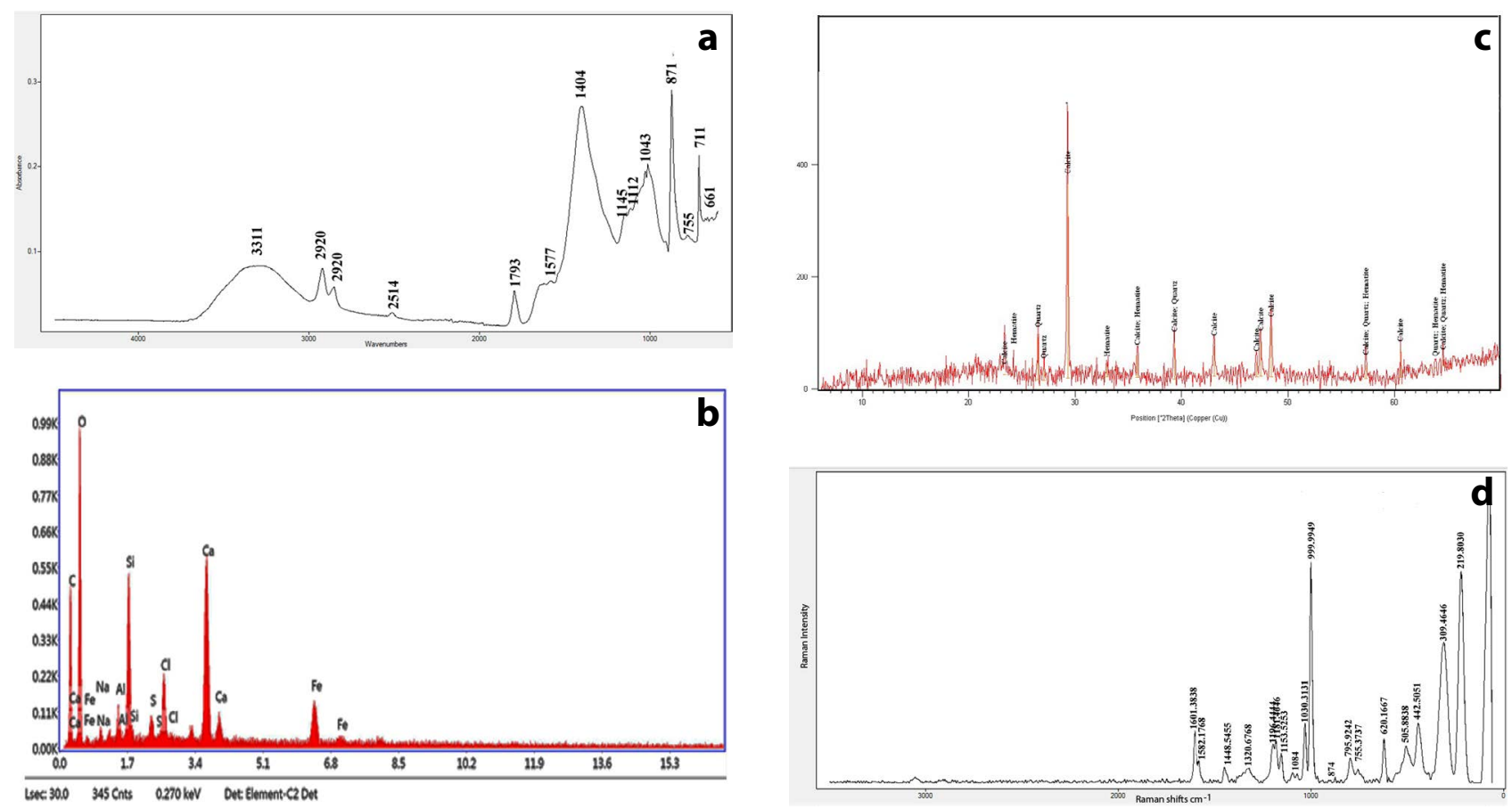

Figure 9. Red pigment: FTIR-ATR $(a) \operatorname{EDX}(b), \operatorname{XRD}(c)$ and Raman $(d)$ spectra. 
of pigments such as red ochre and calcite, or red ochre and gypsum [25].

\section{Green pigment}

Investigation of the green pigment by USB microscopy showed a mixture of yellow and blue grains (Figures 11a-11b). The FTIR-ATR spectrum (Figure 11c) exhibits broad strong bands at 1315 and $1110 \mathrm{~cm}^{-1}$ and two bands at $1024 \mathrm{~cm}^{-1}$. These bands are attributed to symmetrical $\mathrm{Si}-\mathrm{O}-\mathrm{Si}$ stretching vibrations in amorphous silica, while the bands at 771 and $669 \mathrm{~cm}^{-1}$ are assigned to the symmetrical $\mathrm{Si}-\mathrm{O}-\mathrm{Si}$ stretching vibrations in crystalline silica. The bands at 1024,779 and $669 \mathrm{~cm}^{-1}$ are assigned to the symmetrical $\mathrm{Fe}-\mathrm{O}-\mathrm{Fe}$ and $\mathrm{Fe}-\mathrm{O}$ stretching vibrations of goethite $(\mathrm{FeO}(\mathrm{OH}))$. The bands at 3521, 3398 and $3240 \mathrm{~cm}^{-1}$ (asymmetric) are attributed to O-H stretching, and the bands at 1110, 1024 (asymmetric) and $669 \mathrm{~cm}^{-1}$ are $\mathrm{SO}_{4}$ stretching and bending bands of gypsum. The bands at 1409 (asymmetric) and $871 \mathrm{~cm}^{-1}$ are attributed to $\mathrm{CO}_{3}$ stretching and $\mathrm{O}-\mathrm{C}-\mathrm{O}$ bending, respectively, of calcite [21-22].

The EDX analysis showed that the main elements are $\mathrm{Ca}, \mathrm{Si}, \mathrm{Cu}, \mathrm{S}$ and $\mathrm{Fe}$ (Figure 11d). Cuprorivaite, goethite, gypsum and calcite compounds were found in the XRD spectrum (Figure 11e). The results were confirmed by the Raman bands at 1002, 482, 521, $279 \mathrm{~cm}^{-1}$, attributed to goethite, and at 1086, 795, 711, 579, 424 and $365 \mathrm{~cm}^{-1}$, attributed to Egyptian blue (Figure 11f). The bands at 1165, 1002 and $651 \mathrm{~cm}^{-1}$ are attributed to gypsum [32 -33].

The detection of Egyptian blue bands by Raman analysis with a $785 \mathrm{~nm}$ laser was a surprise since the fluorescence of the pigment usually requires the use of a $1064 \mathrm{~nm}$ laser. This occurrence might be attributed to the low percentage of Egyptian blue in the pigment mixture. A green tonality was obtained through a mixture of Egyptian blue, yellow earth and gypsum [25]. The application of such a technique to obtain green colors appeared sporadically in the XIIth Dynasty [36].

\section{Binding medium}

FTIR-ATR analysis of the ground and paint layers in the samples (ground layer, blue, red, pink and green paints) showed consistent spectra with $\mathrm{N}-\mathrm{H}$ stretching bands at $3400-3200 \mathrm{~cm}^{-1}$ and $\mathrm{C}-\mathrm{H}$ stretching bands at $3100-2800 \mathrm{~cm}^{-1}$. The bands at amide I region 1750$1600 \mathrm{~cm}^{-1}$ were attributed to $\mathrm{C}=\mathrm{O}$ stretching, at amide II $1565-1500 \mathrm{~cm}^{-1}$ were attributed to $\mathrm{C}-\mathrm{N}-\mathrm{H}$ bending and at the amide III $1229-1301 \mathrm{~cm}^{-1}$ to $\mathrm{C}-\mathrm{H}$ bending. All of them suggest the presence of a binding based on protein (presumably egg yolk) [18, 37-38].

The bands at 1601, 1582, 1448, 1320, 874 and $755 \mathrm{~cm}^{-1}$ in the Raman spectra are assigned to the binding medium, attributable to egg yolk [39-41]. These results are supported by the availability of eggs from wild birds, such as geese or ducks in ancient Egypt, while domestic chickens were not introduced until classical times. Egg
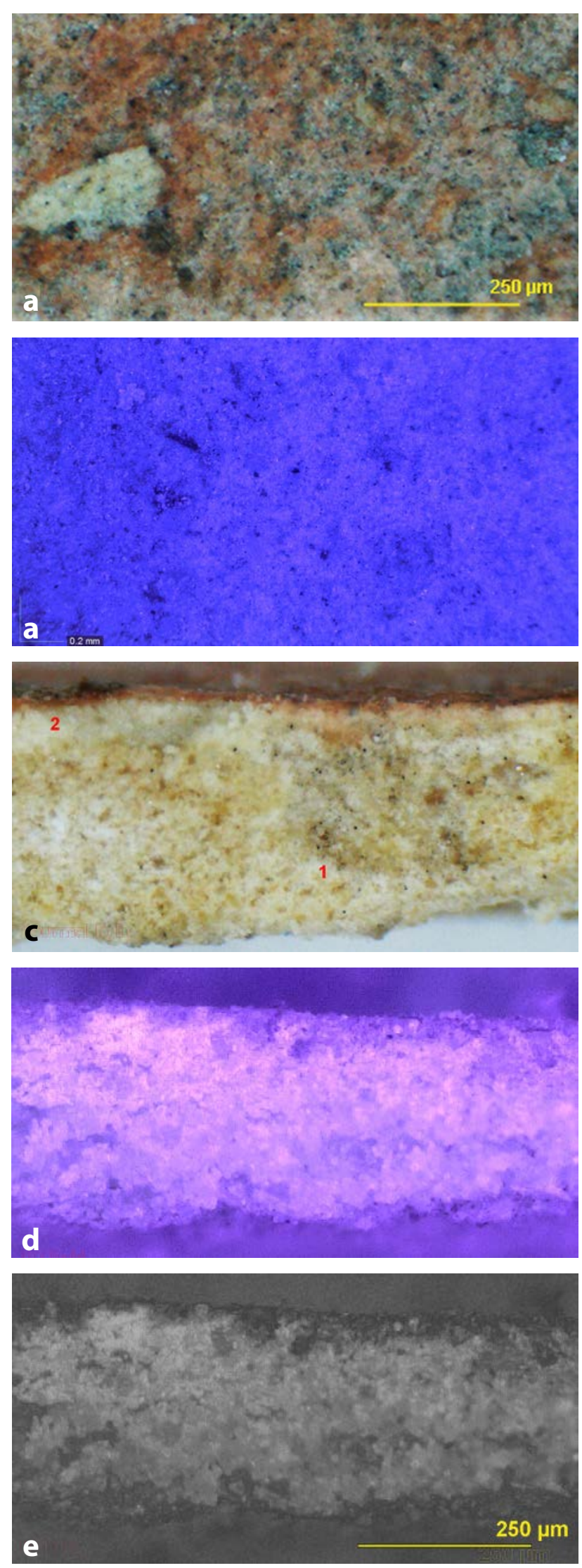

Figure 10. Pink pigment: $a-b$ ) reflected USB microscopy with visible light of pink pigment, consisting of a mixture of red and white grains; the pigment formed a very thin layer as seen in the cross section; $c$-e $)$ reflected USB microscopy with UV and IR light without fluorescence that could be attributed to an organic colorant such as madder lake. 

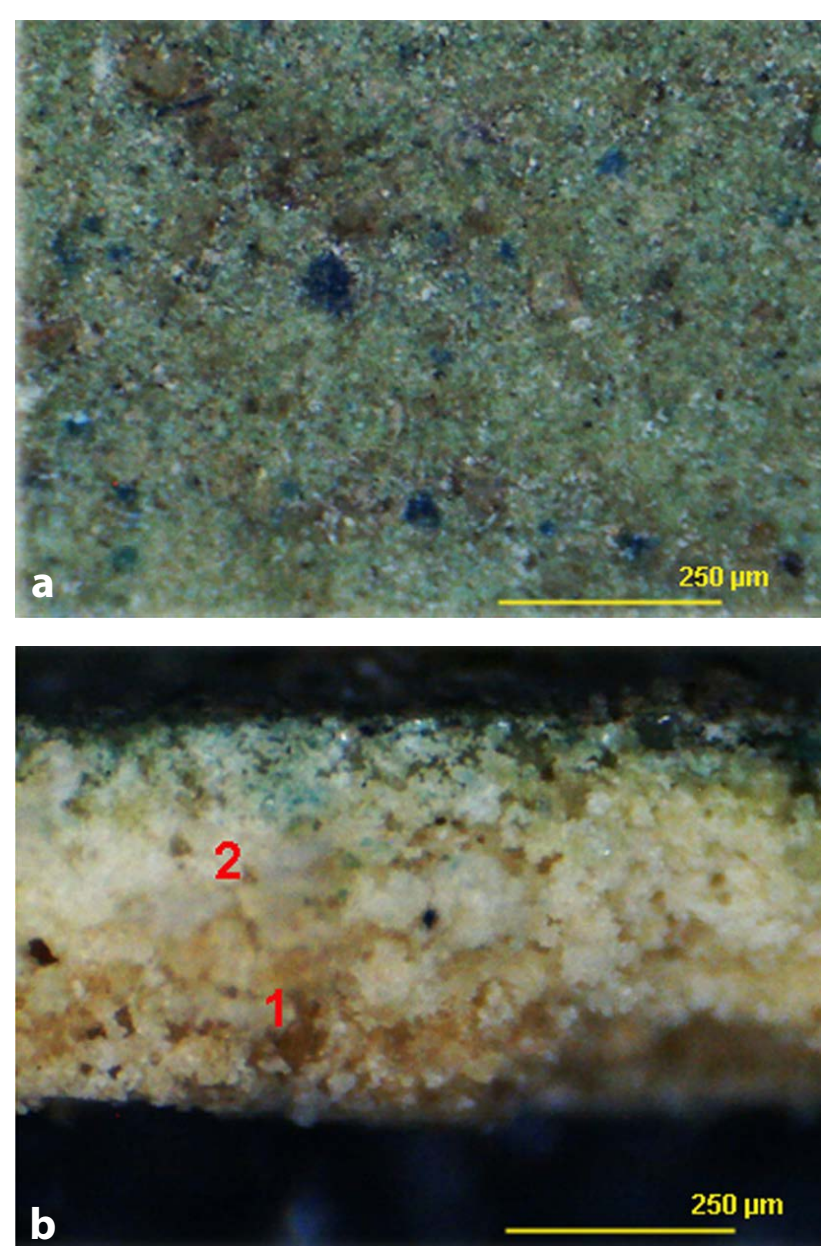

Figure 11. Green pigment: the green pigment with coarse morphology of the surface and blue grains which may have been used in the pigment mixture $(a-b)$; FTIR-ATR $(c)$, EDX $(d)$, $\mathrm{XRD}(e)$ and Raman spectra $(f)$.

yolk can be used as an adhesive or binder, by mixing with water. It is a stable emulsion of an aqueous liquid with an oily protein aqueous medium that dries quickly into a hard, insoluble film [42].

\section{Textile layers}

Investigation by USB digital microscopy and optical microscopy under visible illumination showed that the textile is a $1 / 1$ plain weave structure (Figure 12a) and colored directly with black pigment (Figure 12b). The linen nodes were clearly seen under the optical microscope (Figure 12c). The majority of ancient Egyptian textiles are reported to be made from linen fiber [43-44].

FTIR-ATR spectra suggest that gum was used to bind the black colorant to the textile surface, because the bands at 3435 and $3275 \mathrm{~cm}^{-1}$ (O-H stretching), $2903 \mathrm{~cm}^{-1}(\mathrm{C}-\mathrm{H}$ stretching), $1651 \mathrm{~cm}^{-1}$ (O-H bending), 1434 and $1373 \mathrm{~cm}^{-1}$ (C-H bending) and 1123 and $1092 \mathrm{~cm}^{-1}$ (C-O stretching). No phosphorus bands were detected in the black pigment (Figure 12d). Therefore it is possible to exclude the use of animal sources such as bone black for the colorant and ani-
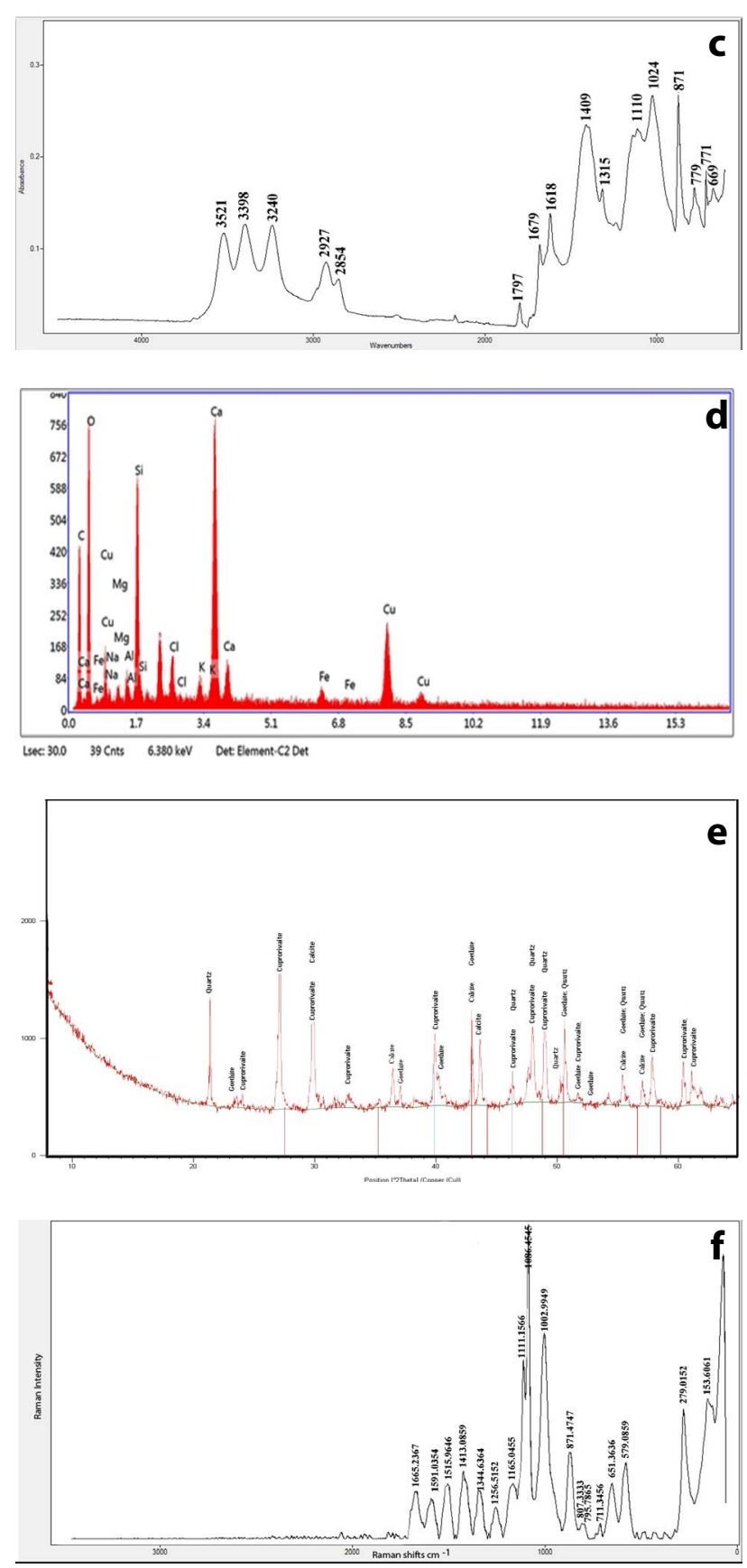

mal glue for the binder. It is therefore suggested that carbon black based on vegetable source was used, mixed with gum as a binding medium. Gum Arabic has been reported to be the most commonly used binding medium in the preparation of paints in ancient Egypt, by extraction from the stem exudate of several species of acacia trees [18, 42].

\section{Salt}

The presence of $\mathrm{Cl}$ and $\mathrm{Na}$ elements in EDX analysis in all paint samples is indicative of the presence of sodium chloride $(\mathrm{NaCl})$. This may probably be related to the burial soil that surrounded the wooden coffin [35] found in the stone sarcophagi, which was buried directly in soil [3]. 


\section{Conclusion}

Multiple analytical studies (portable X-ray radiography, microscopes, FTIR-ATR, EDX, XRD and Raman spectroscopy) were used to determine the materials used in the Ptolemaic wooden coffin lid covered with composite layers at the Egyptian Museum (JE 36806). The identification of wood species indicated that the ancient Egyptian carpenter made the main part of the coffin lid with a native wood Tamarix sp., which was carved to form the coffin. Two preparation layers were observed on the surface of the coffin lid: the first one a coarse-grained ground composed of calcite and quartz, used to minimize the destructive effect of the natural movement of wood, since the coarse and uneven particles of calcite prevent shrinkage of the gesso [7]; the second one, a fine grained layer composed of only calcite, was directly beneath the painted layer.

Pigment analysis confirmed the use of Egyptian blue, red earth, mixture of red earth, calcite and gypsum to obtain the pink hue, and a mixture of Egyptian blue, yellow earth, calcite and gypsum to obtain the green hue. Protein based binding medium (presumably egg yolk) was used in the painted and lower ground layer of the coffin lid, whereas gum Arabic was used in the painted textile layers, mixed with carbon black pigment to color the linen textile surface.
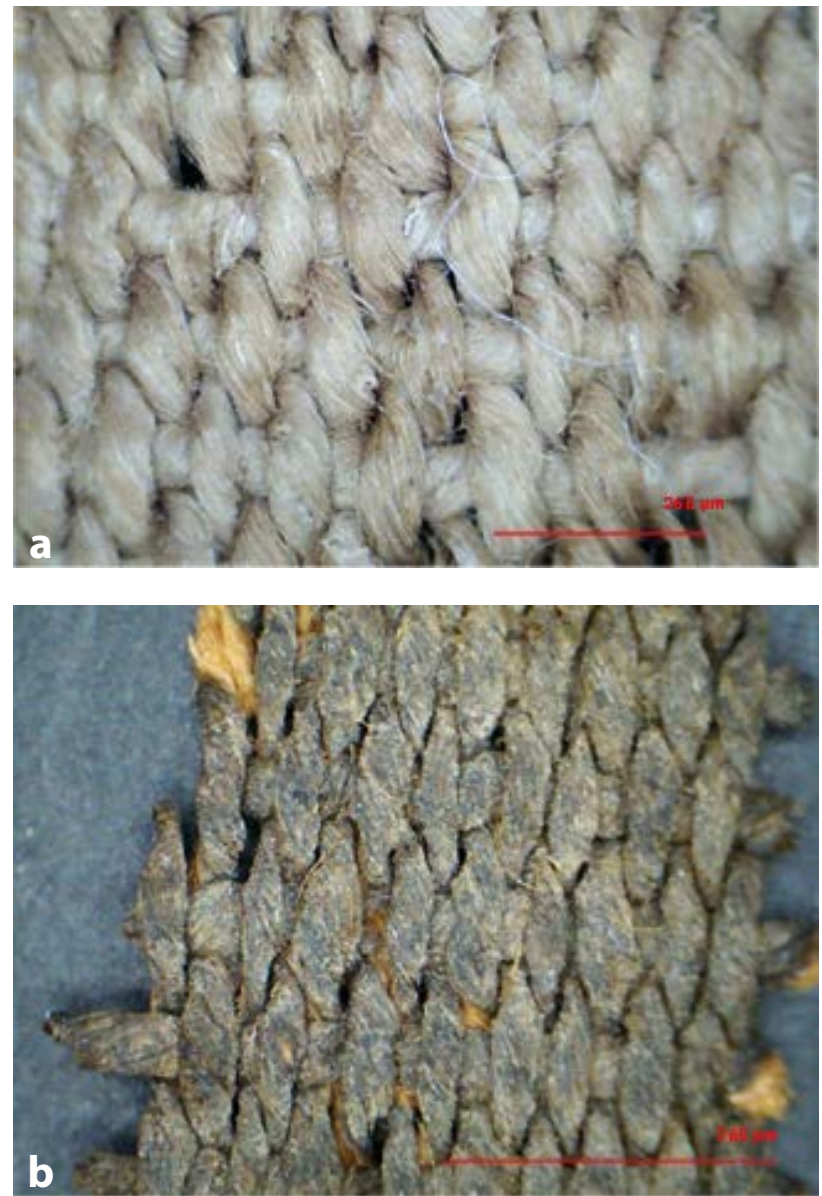

\section{Acknowledgments}

The authors would like to thank Sabah Abd El-Razeq, General Director of the Egyptian Museum, Mariana Jung, from Staatliche museum in Berlin, for providing the Otto Rubenson report and Karim Attia for his efforts in the X-ray radiography.

\section{ORCID}

Nour Mohamed Badr

(D) https://orcid.org/0000-0003-4228-4497

\section{References}

1 Rubensohn, O., 'Bericht über die Ausgrabungen bei Abusir el Mäläq im Jahre 1903', Zeitschrift für Ägyptische Sprache und Altertumskunde 41-42 (1904) 1-21.

2 Bard, K (ed.), Encyclopedia of the Archaeology of Ancient Egypt, Routledge, London - New York (1999).

3 Germer, R.; Kischkewitz, H.; Lüning, M., Berliner Mumiengeschichten: Ergebnisse Eines Multidisziplinaren Forschungsprojektes, Schnell und Steiner, Regensburg (2009).

4 Bruyère, B., Rapport sur les Fouilles de Deir el Médineh (1928), Institut Français d'Archéologie Orientale, Le Caire (1929) 42-43

5 El-Enany, K., 'Un carré de lin peint au musée de l'Agriculture du Caire (inv. 893)', Bulletin de l'Institut Français d'Archéologie Orientale 110 (2010) 35-45.
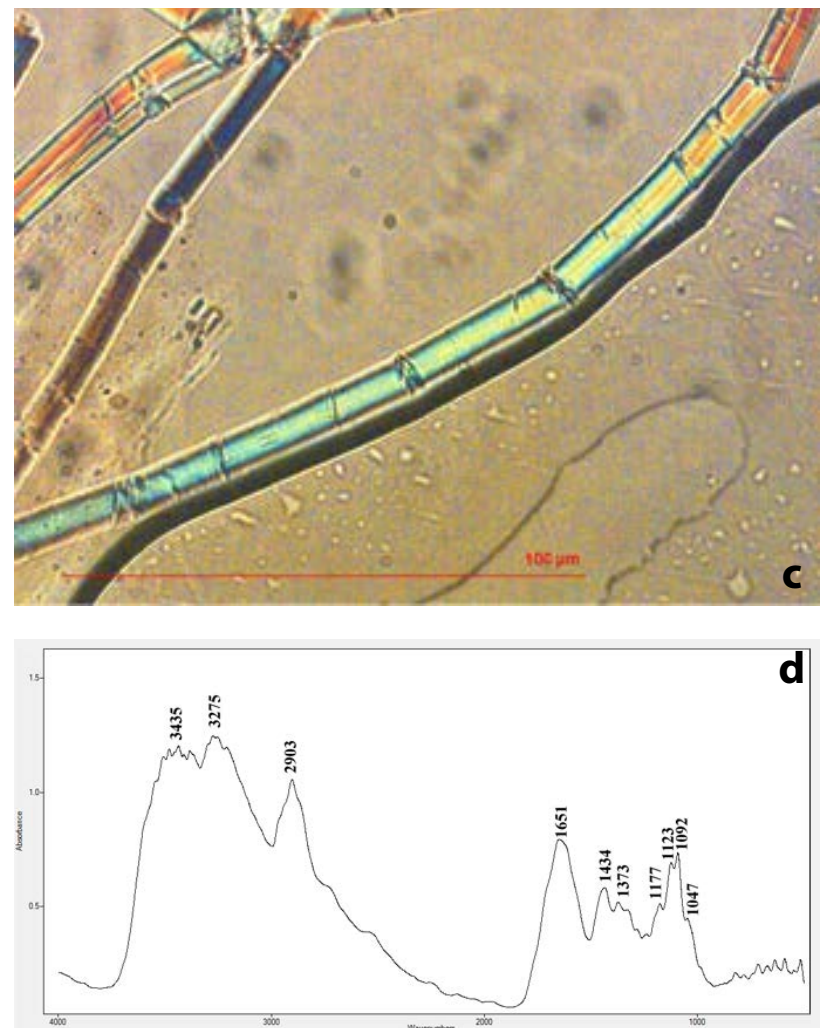

Figure12. a) USB digital microscopy image that shows a structure in plain weave $1 / 1$ and fragile and dry fibers; $b$ ) black pigment applied directly on the textile fabric surface; $c$ ) the internal structure of the fiber with nodes characteristic of linen; d) FTIR spectrum of the black pigment on the textile surface. 
6 Valdemar, S., Sarkofager, Mumiekister og Mumiehylstre $i$ det Gamle Aegypten, J. Frimodt, København (1919).

7 Dawson, J.; Marchant, J.; Von Aderkas, E.; Cartwright, C.; Stacey, R., 'Egyptian coffins: materials, construction and decoration', in Death on the Nile Uncovering the Afterlife of Ancient Egypt, ed. H. Strudwick \& J. Dawson, Fitzwilliam Museum, Cambridge (2016) 75-111.

8 Wheeler, E. A.; Baas, P.; Gasson, P. E. (ed.), "IAWA List of microscopic features for hardwood identification: with an appendix on non-anatomical information', IAWA Bulletin 10 (3) (1989) 219-332, https://doi.org/10.1163/2294193290000496.

9 Anđelković, B.; Victoria, M.; Amorós, A., 'The coffin of Nesmin: construction and wood identification', Journal of the Serbian Archaeological Society 21 (2005) 349-364.

10 Schweingruber, F.H.; Börner, A.; Schulze, E., Atlas of Stem Anatomy in Herbs, Shrubs and Trees, Springer, Berlin Heidelberg (2011).

11 Crivellaro, A. ; Schweingruber, F. H., Atlas of Wood, Bark and Pith Anatomy of Eastern Mediterranean Trees and Shrubs with a Special Focus on Cyprus, Springer, Berlin Heidelberg (2013).

12 Gale, R.; Gasson, P.; Hepper, N.; Killen, G., 'Wood', in Ancient Egyptian materials and technology, ed. P. Nicholson \& I. Show, Cambridge University Press, Cambridge (2000) 334-370.

13 Gansicke, S., 'The conservation of decorated organic Egyptian surfaces: a literature review', in Decorated Surfaces on Ancient Egyptian Objects: Technology, Deterioration and Conservation, ed. J. Dawson, C. Rozeik \& M. Wright, Archetype Publications, Cambridge (2010) 67-77.

14 Stein, A.; Lacovara, P., 'Observations on the preparation layers found on ancient Egyptian decorated coffins', in Decorated Surfaces on Ancient Egyptian Objects: Technology, Deterioration and Conservation, ed. J. Dawson, C. Rozeik \& M. Wright, Archetype Publications, Cambridge (2010) 3-8.

15 Sadegh, A.; Kiaei, M.; Samariha, A., 'Experimental Characterization of Shrinkage And Density of Tamarix Aphylla Wood', Cellulose Chemistry and Technology 46 (2012) 369-373.

16 Mecklenburg, M. F.; Tumosa, C. S.; Erhardt, D., 'Structural response of painted wood surfaces to changes in ambient relative humidity', in Painted Wood: History and Conservation, ed. V. Dorge \& C. Howlett, Getty Conservation Institute, Los Angeles (1998) 464.

17 Killen, G., Ancient Egyptian Furniture, vol.1, Oxbow Books, Oxford (2017) 7.

18 Derrick, M.; Stulik, C. Landry, J., Infrared Spectroscopy in Conservation Science, Getty Publications, Los Angeles (1999) 179-183.

19 Lucas, A.; Harris, J.R., Ancient Egyptian Materials and Industries, 4th ed., Edward Arnold, London (1962).

20 Scott, D. A.; Warmlander, S.; Mazurek, J.; Quirke, S., Examination of some pigments, grounds and media from Egyptian cartonnage fragments in the Petrie MuseumUniversity College London', Journal of Archaeological Science, 36 (3) (2009) 923-932, https://doi.org/10.1016/j. jas.2008.12.011.

21 Mahmoud, H., 'A multi-analytical approach for characterizing pigments from the tomb of Djehutyemhab (Tt194), Elqurna necropolis, Upper Egypt', Archeometriai Mühely 3 (2012) 205-214.

22 Mahmoud, H. H. M., 'Investigations by Raman microscopy, ESEM and FTIR-ATR of wall paintings from Qasr elGhuieta temple, Kharga Oasis, Egypt', Heritage Science 2 (2014) 18. https://doi.org/10.1186/s40494-014-0018-x.

23 Westlake, P.; Siozos, P.; Philippidis, A.; Apostolaki, C.; Derham, B.; Terlixi, A.; Perdikatsis, V.; Jones, R. ; Anglos,
D. , 'Studying pigments on painted plaster in Minoan, Roman and early Byzantine Crete. A multi-analytical technique approach', Analytical and Bioanalytical Chemistry 402(4) (2012) 1413-1432, https://doi.org/10.1007/s00216011-5281-z.

24 Lee, L.; Quirke, S., 'Painting materials', in Ancient Egyptian Materials and Technology, ed. P. Nicholson \& I. Show, Cambridge University Press, Cambridge (2000) 104-119.

25 Scott, D. 'A review of ancient Egyptian pigments and cosmetics', Studies in Conservation 61(4) (2016) 185-202, http://dx.doi.org/10.1179/2047058414Y.0000000162.

26 Jaksch, H.; Seipel, W.; Weiner, K.; E1 Goresy, A., 'Egyptian blue - Cuprorivaite a window to ancient Egyptian technology', Naturwissenschaften 70(11) (1983) 525-535, https://doi.org/10.1007/BF00376668.

27 Bianchetti, P.; Talarico, F.; Vigliano, M. G.; Ali, M. F., 'Production and characterization of Egyptian blue and Egyptian green frit', Journal of Cultural Heritage 1(2) (2000) 179-188, https://doi.org/10.1016/S1296-2074(00)00165-5.

28 Hatton, G. D.; Shortland, A. J.; Tite, M. S., 'The production technology of Egyptian blue and green frits from second millennium BC Egypt and Mesopotamia', Journal of Archaeological Science 35(6) (2008) 1591-1604, https://doi. org/10.1016/j.jas.2007.11.008.

29 Di Stefano, L.M.; Fuchs, R., 'Characterization of the pigments in a Ptolemaic Egyptian Book of the Dead papyrus', Archaeological and Anthropological Sciences 3 (2011) 229-244, https://doi.org/10.1007/s 12520-011-00543.

30 Ambers, J., 'Raman analysis of pigments from the Egyptian Old Kingdom', Journal of Raman Spectroscopy 35 (8-9) (2004) 768-773, https://doi.org/10.1002/jrs.1187.

31 Bersani, D.; Lottici, P. P., 'Raman spectroscopy of minerals and mineral pigments in archaeometry', Journal of Raman Spectroscopy 47(5) (2016) 499-530, https://doi.org/10.1002/ jrs.4914.

32 Burgio, L.; Clark , R., 'Library of FT-Raman spectra of pigments, minerals, pigment media and varnishes, and supplement to existing library of Raman spectra of pigments with visible excitation', Spectrochimica Acta Part A 57(7) (2001) 1491-1521, https://doi.org/10.1016/S13861425(00)00495-9.

33 David, A.; Edwards, H.; Farwell, W.; De Faria, D., 'Raman spectroscopic analysis of ancient Egyptian pigments', Archaeometry 43(4) (2001) 461-473, https://doi. org/10.1111/1475-4754.00029.

34 Hanesch, M., 'Raman spectroscopy of iron oxides and (oxy) hydroxides at low laser power and possible applications in environmental magnetic studies', Geophysical Journal International 177(3) (2009) 941-948, https://doi. org/10.1111/j.1365-246X.2009.04122.x.

35 Abdrabou, A.; Abdallah, M.; Kamal, H., 'Scientific investigation by technical photography, OM, ESEM, XRF, $\mathrm{XRD}$ and FTIR of an ancient Egyptian polychrome wooden coffin', Conservar Património 26 (2017) 51-63, https://doi. org/10.14568/cp2017008.

36 Ragai, J., 'Colour: its significance and production in Ancient Egypt', Endeavour 10 (2) (1986) 74-79, https://doi. org/10.1016/0160-9327(86)90134-1.

37 Vahur, S.; Teearu, A.; Peets, P.; Joosu, L.; Leito, I., 'ATRFT-IR spectral collection of conservation materials in the extended region of 4000-80 cm-1 , Analytical and Bioanalytical Chemistry 408 (13) (2016) 3373-3379, https:// doi.org/10.1007/s00216-016-9411-5.

38 'ATR-FT-IR spectra of egg yolk (4000-225 cm-1)', in Database of ATR-FT-IR Spectra of Various Materials, http://lisa.chem.ut.ee/IR_spectra/paint/binders/egg-yolk/ (accessed 2017-1-31). 
39 Vandenabeele, P.; Wehling, B.; Moens, L.; Edwards, H.; De Reu, M.; Van Hooydonk, G., 'Analysis with micro-Raman spectroscopy of natural organic binding media and varnishes used in art', Analytica Chimica Acta 407(1-2) (2000) 261274, https://doi.org/10.1016/S0003-2670(99)00827-2.

40 Nevin, A.; Osticioli, I. ; Anglos, D.; Burnstock, A.; Cather, S.; Castellucci, E., 'The analysis of naturally and artificially aged protein-based paint media using Raman spectroscopy combined with Principal Component Analysis', Journal of Raman Spectroscopy 39(8) (2008) 993-1000, https://doi. org/10.1002/jrs.1951.

41 Osticioli, I.; Nevin, A.; Anglos, D.; Burnstock, A.; Cather, S.; Becucci, M.; Fotakis, C.; Castellucci, E., 'Micro-Raman and fluorescence spectroscopy for the assessment of the effects of the exposure to light on films of egg white and egg yolk', Journal of Raman Spectroscopy 39(2) (2008) 307313, https://doi.org/10.1002/jrs.1915.

42 Newman, R. ; Serpico, M., 'Adhesives and binders', in Ancient Egyptian Materials and Technology, ed. P. Nicholson \& I. Show, Cambridge University Press, Cambridge (2000) 475-490.
43 Vogelsang-Eastwood, G., 'Textiles', in Ancient Egyptian Materials and Technology, ed. P. Nicholson \& I. Show, Cambridge University Press, Cambridge (2000) 268-297.

44 Borojevic, K.; Mountain, R., 'Microscopic identification and sourcing of ancient Egyptian plant fibres using longitudinal thin sectioning', Archaeometry, 55(1) (2013) 81-112, https:// doi.org/10.1111/j.1475-4754.2012.00673.x.

Received: 2017-6-2

Revised: 2017-10-29

Accepted: 2017-11-30

Online: $2018-2-1$

This work is licensed under the Creativer Attribution-NonCommercial-NoDerivatives 4.0 International License.

To view a copy of this license, visit http://creativecommons.org/licenses/by-nc-nd/4.0/deed.en. 